\title{
A Study on the Influence of E-Commerce Live Streaming on Consumer Repurchase Intentions
}

\author{
Yifei Chen ${ }^{1}$, Feiyan $\mathrm{Lu}^{2} \&$ Siyu Zheng ${ }^{1}$ \\ ${ }^{1}$ Jinling high school Hexi campus, Nanjing, Jiangsu, China \\ ${ }^{2}$ School of Business, Nanjing University, Nanjing, China \\ Correspondence: Siyu Zheng, Jinling high school Hexi campus, Nanjing, Jiangsu, China. E-mail: \\ 2080984627@qq.com
}

Received: August 23, 2020

Accepted: October 25, 2020 Online Published: November 27, 2020

doi:10.5539/ijms.v12n4p48

URL: https://doi.org/10.5539/ijms.v12n4p48

\begin{abstract}
The year 2019 witnessed an exponential growth of the e-commerce live streaming industry. Notably, competitions among live streamers have become increasingly fierce as more newcomers are marching in. To survive and thrive in the cut-throat market competitions, it is key for them to increase consumers' repeat purchase rate and win customer loyalty. This study uses empirical research methods to probe into the influence of e-commerce live streaming on consumer repurchase intentions. According to this study, perceived entertainment and perceived similarity have a positive impact on consumer repurchase intentions, and this relationship is partially mediated by consumer satisfaction. In addition, perceived product quality, perceived interactivity, and perceived professionalism have a positive and indirect effect on consumer repurchase intentions, and this relationship is fully mediated by consumer satisfaction.
\end{abstract}

Keywords: e-commerce live streaming, repeat purchase, consumer satisfaction

\section{Introduction}

Since Taobao Live started trial operation in 2016, e-commerce live streaming has been booming as webcast technologies are growing by leaps and bounds and venture capitalists are increasing their bet on the industry. With the rise of live streamers Li Jiaqi (nicknamed the "Lipstick King") and Viya (nicknamed the "Live Streaming Queen") in 2019, the whole industry experienced explosive development. That is why the year 2019 is considered as the first year of the e-commerce live streaming era. Statistics show that the market size of live streaming has skyrocketed to RMB 433.8 billion from RMB 19 billion three years ago, becoming a 100 billion-level emerging industry.

E-commerce live streaming is faring well, but the competition among live streamers is getting harsh as more and more people are cramming into the market. Top influencer Li Jiaqi once said in an interview that he cannot afford to take a rest even if he is sick, because "tens of thousands live broadcasts are made on Taobao each day. If I take a day off, my followers may turn to other live streamers." This illustrates that customer retention is the key for e-commerce live streamers to survive the fierce competition and secure a sustainable development. To retain customers is to increase customer stickiness and build customer loyalty. Customer loyalty is represented by repeat purchases, according to a study by Shankar et al. (2003).

Therefore, it is necessary and important to explore the influence of e-commerce live streaming on consumer repurchase intentions and the mechanism behind. On the one hand, the study can offer practical suggestions to help e-commerce live steamers enhance customer stickiness and customer loyalty. On the other hand, it can facilitate the sustainable development of e-commerce live streaming by improving the repeat purchase rate across the industry.

So what are the factors that can affect the repurchase intentions? By reviewing, sorting out, and summarizing the previous literatures, the authors found that most research on consumers' buying decisions made in e-commerce live streams focuses on either the live broadcasting scenario or streamers/key opinion leaders (KOLs). In terms of studies based on live broadcasting scenarios, Dan Mingxiao and Wu Feng (2018) believed that factors like the entertainment of live broadcasts and the promotional pricing under the circumstances pose a significant influence on consumer purchase intentions. Wang Xiujun, Wang Wen and Sun Nannan (2019) defined e-commerce live 
streaming features as entertainment, discount, and interactivity, and discussed how these factors affect consumer intentions and behaviors by emotional and cognitive changes (the mediator) based on the S-O-R theory. With regard to studies centering on streamers/KOLs, Xiang et al. (2016) believed that KOLs' features such as professionalism and similarity influence consumer repurchase intentions by consumer satisfaction and other variables. Bansal and Voyer (2000) analyze the impact of the characteristics of professional, interactive on consumers' willingness to purchase; Thus, it can be concluded that the main features of the e-commerce live streaming scenario are entertainment and discount, and those of streamers include interactivity, professionalism, and similarity. In addition, Fang et al. (2016) pointed out that product quality is a key factor influencing consumer repurchase intentions. Therefore, product quality is also included in this study as the product factor.

Upon analysis, the study has determined the factors that affect consumer repurchase intentions in e-commerce live streams. But how do these factors influence consumer repurchase intentions? To this end, this study has retrospectively analyzed the literature about repeat purchase and continuous usage. Perceived value indirectly affects consumes' repeat purchase or continuous usage via the mediator of satisfaction, as revealed by studies of Patterson and Spreng (1997), and Chiu et al. (2005). Besides, Bhattacherjee (2001) pointed out in her research on information system that expectation confirmation, perceived entertainment, and perceived usefulness affect users' continuous usage intentions via the mediator of satisfaction. Based on these studies, it can be perceived that satisfaction is the key factor influencing consumer repurchase intentions and it often serves as a mediator to explain the mechanism behind. Therefore, consumer satisfaction has been used as the mediator in this study.

To sum up, this study probes into how e-commerce live streaming affects consumer repurchase intentions and what role consumer satisfaction plays in this process based on three factors: products (perceived product quality), e-commerce live streaming scenarios (perceived entertainment and perceived discount), and streamers (perceived interactivity, perceived professionalism, and perceived similarity).

This study is profound in two aspects: For starters, it is the first-ever theoretical study focusing on consumers' repurchase behavior in the e-commerce live streaming scenario, and it serves as a theoretical supplement to the existing research on repeat purchase and customer loyalty. Secondly, this study has expanded the theoretical perspectives of research on consumer behavior in the e-commerce live streaming scenario as it takes products factor, e-commerce live streaming scenarios, and streamers into account for the first time.

\section{Theoretical Basis and Research Hypothesis}

\subsection{Theoretical Basis}

The ABC model of attitudes is a theoretical model that describes how an attitude form. Every attitude has three components represented in the model: affect, behavior, and cognition, which are interlinked. According to Rosenberg and Hovland (1960), in the ABC model of attitudes, the affective component refers to the emotional reaction one has toward an attitude object, the behavioral component refers to the way one behaves when exposed to an attitude object, and the cognitive component refers to the beliefs and knowledge about an attitude object. In practice, researchers use hierarchical effect to interpret the interrelationship among the three components. The standard-learning hierarchy based on cognitive information processing is reflected as C-A-B, which means a consumer will establish beliefs (Cognition) and then feelings (Affect) about an attitude object, which are followed by the consumer's behavior. The low-involvement hierarchy based on the behavioral learning process consists of the order of C-B-A, which means a consumer bases their purchase decision on what they know as opposed to what they feel, that is, they establish feelings about a product after the purchase. The experiential hierarchy based on hedonism is defined by a processing order of A-B-C. In this scenario, the consumer is influenced to purchase based entirely on their feelings about a product, which is followed by cognition.

In fact, the ABC model of attitudes is often used to study the buying behavior of consumers. Hsu et al. (2015) employed the model to discuss how credibility and consumer satisfication affect consumer repurchase intentions.

Using the standard-learning hierarchy of the model (C-A-B) as the theoretical guidance, this study has established a research model where "perceived factors of products, e-commerce live streaming scenarios, and streamers influence consumer repurchase intentions by affecting consumer satisfaction". This study has established an $\mathrm{ABC}$ model by defining the perceived factors as cognition, consumer satisfaction as affect, and consumer repurchase intention as behavior.

\subsection{Research Hypothesis}

2.2.1 Repurchase Intentions and Factors of Products, E-Commerce Live Streaming Scenarios, Streamers

Perceived product quality is consumers' overall assessment of the product quality when they use the product. For 
both online and offline merchants, product quality exerts an enormous influence on consumers' purchase intentions, and repurchase intentions in particular. If consumers have faith in the quality of one merchant's products, they may well buy again from the merchant. Many scholars have proved the impact of product quality on purchase or repurchase intentions. Ling et al. (2010) points out that product quality and shopping experience will positively affect consumers' willingness to buy. Kim (2008) noted that product quality has a positive effect on consumer repurchase intentions by dint of trust and satisfaction. Based on the above analysis, the authors propose the following hypothesis:

H1: Perceived product quality has a positive impact on repurchase intentions.

Perceived entertainment is the pleasure consumers gain from e-commerce live streams. In most cases, pleasant shopping experience will leave consumers a good impression, which will motivate them to buy again. Chang and Cheung (2001) validated this claim in their study on website users. They discovered that users will often visit the websites where they find pleasure. Lin et al. (2004) also pointed out that perceived entertainment is a reflection of users' intrinsic motivation and it positively influences their behavior. The research by Schmidt and Spreng (1996) on video websites shows that perceived entertainment has a positive effect on users' continuous usage intentions. Bouwman et al. (2006) held that entertainment plays a positive role in influencing consumers' buying decisions, which include repeat purchases. Based on the above analysis, the authors propose the following hypothesis:

H2: Perceived entertainment has a positive impact on repurchase intentions.

Most live stream shoppers believe they can enjoy special offers that are unavailable from other shopping channels, such as bigger discounts or more gifts. Thus, it can be seen that perceived discount also greatly affects consumers' buying decisions in e-commerce live streams, and repeat purchase is a kind of buying decision. According to the empirical research by Kim and Kramer (2006), perceived discount positively affects continuous usage intentions. Based on the above analysis, the authors propose the following hypothesis:

H3: Perceived discount has a positive impact on repurchase intentions.

Because of the high interactivity of e-commerce live streams, consumers can communicate and interact with live streamers in real time, closing their emotional gaps. Meanwhile, streamers can field consumers' questions about products, allaying consumers' concerns over uncertainties and enhancing their shopping experience. As a result, consumers become more glued to the streamers, which often leads to repeat purchases. This has been validated by many scholars. Research by Xue and Phelps (2004) suggests that people are more likely to be influenced by consumer attitudes which presentated by consumer satisfaction in their interactions with opinion leaders than by information published on the platform. Based on the above analysis, the authors propose the following hypothesis:

H4: Perceived interactivity has a positive impact on repurchase intentions.

Based on the professional knowledge provided by streamers in e-commerce live broadcasts, consumers can have a full understanding of the relevant products, thus make their buying decisions with fewer uncertainties. That is to say, in e-commerce live streams, streamers' job is to use their knowledge about products to persuade consumers to make purchases. Research findings by Chan and Misra (1990) show that KOLs'professional knowledge will encourage consumers to make buying decisions. Bansal and Voyer (2000) pointed out that the professionalism of KOLs can add luster to their sales pitches, predisposing consumers to make quicker buying decisions. In essence, live streamers are KOLs in webcasts. Repeat purchase is also a buying decision. Based on the above analysis, the authors propose the following hypothesis:

\section{H5: Perceived professionalism has a positive impact on repurchase intentions.}

Perceived similarity is the similarity that consumers perceive with streamers in personality, style, taste, product preference, values, etc. As a saying goes, birds of a feather flock together. Ruef et al. (2003) concluded that individuals are innately more willing to spend time with like-minded people and accept them more easily. In e-commerce live streams, consumers tend to approve of and recognize streamers with some similar personal traits, so they are more inclined to be persuaded by these streamers to make purchase decisions. Gilly et al. (1998) confirmed that similarity has a positive effect on persuasiveness. According to the study by Xiang et al. (2016), similarity plays a positive role in forming quasi-social interaction, which has an indirect effect on repeat purchase intention. Based on the above analysis, the authors propose the following hypothesis:

H6: Perceived similarity has a positive impact on repurchase intentions. 


\subsubsection{Consumer Satisfaction and Factors of Products, E-Commerce Live Streaming Scenarios, and Streamers}

Perceived product quality is consumers' overall assessment of the product quality when they use the product. Generally speaking, the higher a consumer's perceived product quality is, the better shopping experience and satisfaction they will have. Murgulets et al. (2001) found that customer satisfaction depends on the perceived quality of the product or service compared to the expected level, and if the perceived quality of the product or service is higher than the expected level, the degree of customer satisfaction and the customer's intention to repeat the purchase will be enhanced. Based on the above analysis, the authors propose the following hypothesis:

H7: Perceived product quality has a positive impact on consumer satisfaction.

Perceived entertainment is the pleasure consumers gain from e-commerce live streams. Generally, a consumer's pleasure in shopping is proportional to their satisfaction. Schlosser et al. (1999) examined the positive influence of perceived entertainment on satisfaction in her research on Internet advertising. Lin et al. (2004) also reached the same conclusion. Based on the above analysis, the authors propose the following hypothesis:

\section{H8: Perceived entertainment has a positive impact on consumer satisfaction.}

More often than not, in e-commerce live streams, consumers can enjoy more benefits than any other shopping channel can provide, such as higher discounts or more gifts. Consumers would be very satisfied with their shopping experience if they have perceived extra benefits a streamer provides. In a study on online food ordering by university students, Chen Zhengxiong and Lu Fang (2018) pointed out that perceived discount has a positive impact on consumer satisfaction. Peng Xiao (2016) drew a conclusion based on a study on online group buying that perceived discount positively affects consumer satisfaction. Based on the above analysis, the authors propose the following hypothesis:

H9: Perceived discount has a positive impact on consumer satisfaction.

In e-commerce live streams, interactivity plays an important role in affecting consumers' buying decisions. The high interactivity of e-commerce live streams makes consumers feel like they are talking to streamers face-to-face. They can enjoy better services as streamers can field their questions about products in real time, thus improving their shopping satisfaction. The research on the relationship between interactivity and satisfaction is a well-trodden path. Yoo et al. (2012) demonstrated that interactivity has a positive impact on consumer satisfaction. Skadberg and Kimmel (2004) pointed out that under the interaction of computer-mediated communication, the user's purchasing experience can be enhanced, thus resulting in a higher degree of satisfaction with online shopping. Based on the above analysis, the authors propose the following hypothesis:

H10: Perceived interactivity has a positive impact on consumer satisfaction.

The professionalism of e-commerce live streamers is shown by how well they know about the products they are promoting, such as product properties and usage. It directly determines how consumers perceive the product information they provide, thereby affecting consumer satisfaction. Some scholars used empirical analysis to prove the point. Gilly et al. (1998) validated that the professionalism of word-of-mouth sender can reduce consumers'perceived risk, reduce consumers'concerns about products, and have a positive impact on consumers' attitudes represented by consumer satisfaction. Based on the above analysis, the authors propose the following hypothesis:

H11: Perceived professionalism has a positive impact on consumer satisfaction.

It is streamers who persuade consumers to make buying decisions in e-commerce live streams. If consumers believe that they have something in common with a streamer, they would pay closer attention to and nod greater recognition of the streamer, thus increasing the shopping satisfaction. The study by Xiang et al. (2016) attested to the positive effect of similarity on consumer satisfaction. Based on the above analysis, the authors propose the following hypothesis:

H12: Perceived similarity has a positive impact on consumer satisfaction.

\subsubsection{Consumer Satisfaction and Repurchase Intentions}

In a study on consumers' actual purchase behavior, Bolton and Drew (1991) found that satisfaction has a significant impact on the consumer behavior, which is represented by repurchase intention. In fact, many scholars, such as Thong et al. (2006), Kim (2010), have substantiated the considerable impact of consumer satisfaction on repeat purchases or continuous usage. Zhou and Tao (2011) noted that consumer satisfaction, as a prerequisite for customer loyalty, has an enormous impact on consumers' behavioral loyalty. When Cardozo (1965) put forward the concept of customer satisfaction, it shows that consumer satisfaction is an important factor affecting consumer repurchase intentions. Based on the above analysis, the authors propose the following 
hypothesis:

H13: Consumer satisfaction has a positive impact on repurchase intentions.

\subsubsection{Mediation Effect of Consumer Satisfaction}

In the light of the standard-learning hierarchy of the $\mathrm{ABC}$ model of attitudes, Cognition influences Behavior through the mediation of Affect. In this study, cognition refers to the factors of products (perceived product quality), e-commerce live streaming scenarios (perceived entertainment and perceived discount), and streamers (perceived interactivity, perceived professionalism, and perceived similarity); affect is defined as consumer satisfaction; and behavior points to repurchase intentions. Therefore, based on the standard-learning hierarchy, perceived factors $(\mathrm{C})$ influence consumer satisfaction (A), which further affects repurchase intentions (B). Based on the above analysis, the authors propose the following hypotheses:

H14: Consumer satisfaction mediates the relationship between perceived product quality and repurchase intentions.

H15: Consumer satisfaction mediates the relationship between perceived entertainment and repurchase intentions.

H16: Consumer satisfaction mediates the relationship between perceived discount and repurchase intentions.

H17: Consumer satisfaction mediates the relationship between perceived interactivity and repurchase intentions.

H18: Consumer satisfaction mediates the relationship between perceived professionalism and repurchase intentions.

H19: Consumer satisfaction mediates the relationship between perceived similarity and repurchase intentions.

\subsection{Research Model}

Based on the ABC model of attitudes (C-A-B) and the hypotheses proposed, the theoretical model for this study is shown as Figure 1.

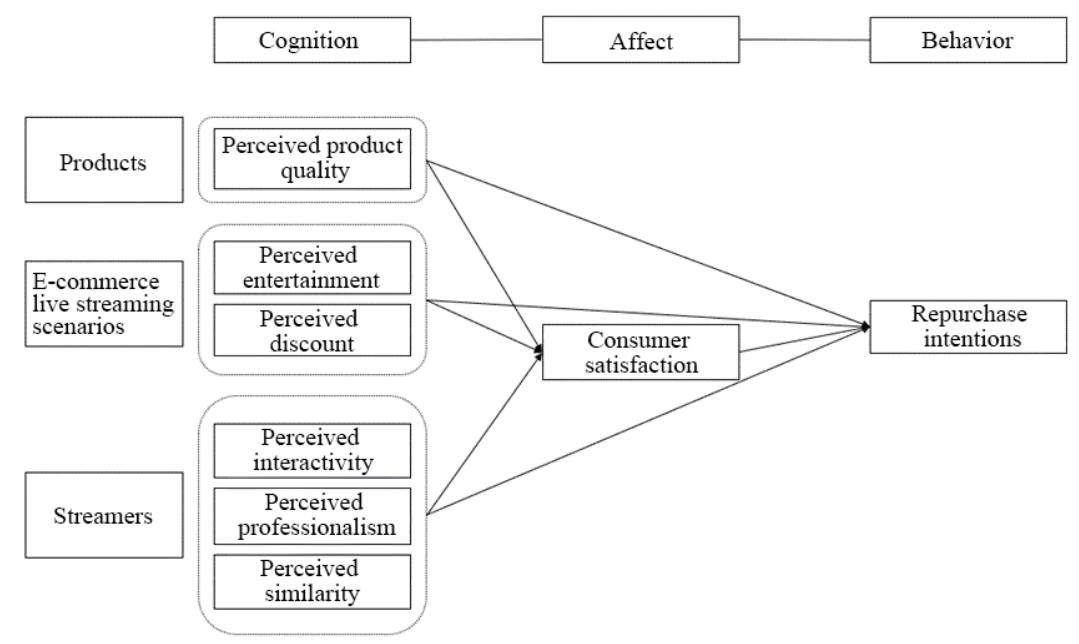

Figure 1. Theoretical model

\section{Empirical Analysis}

\subsection{Definitions and Measurement of Variables}

This study involves eight variables: perceived product quality, perceived entertainment, perceived discount, perceived interactivity, perceived professionalism, perceived similarity, consumer satisfaction, and repurchase intentions. The definitions and measurements of these variables are displayed in Tables 1 and 2 respectively. 
Table 1. Variable definitions in different studies

\begin{tabular}{|c|c|c|c|}
\hline Name & Code & Definition & Reference \\
\hline Perceived product quality & PPQ & Consumers' overall assessment of the product quality & $\begin{array}{l}\text { Brucks et al. (2000) and Kim } \\
\text { (2008) }\end{array}$ \\
\hline Perceived entertainment & PE & $\begin{array}{l}\text { Consumers' perception of pleasure gaining from e-commerce } \\
\text { live streams }\end{array}$ & Moon and Kim (2001) \\
\hline Perceived discount & $\mathrm{PD}$ & $\begin{array}{l}\text { Consumers' perception of benefits from e-commerce live } \\
\text { streams }\end{array}$ & Xu Lian (2011) \\
\hline Perceived interactivity & PI & $\begin{array}{l}\text { Consumers' perception of real-time communication with } \\
\text { streamers }\end{array}$ & Ghose and Dou (1998) \\
\hline Perceived professionalism & PP & $\begin{array}{l}\text { Consumers' perception of how well streamers know about the } \\
\text { products they are selling, how much related professional } \\
\text { knowledge they have, and how useful their information is for } \\
\text { purchase decisions }\end{array}$ & $\begin{array}{l}\text { Gilly et al. (1998) and Xiang } \\
\text { et al. (2016) }\end{array}$ \\
\hline Perceived similarity & PS & $\begin{array}{l}\text { Consumers' perception of the similarity with streamers in } \\
\text { personal traits such as personality, style, taste, product } \\
\text { preference, and values }\end{array}$ & $\begin{array}{l}\text { Xiang et al. (2016) and } \\
\text { Rogers and Bhowmik (1970) }\end{array}$ \\
\hline Consumer satisfaction & $\mathrm{CS}$ & $\begin{array}{l}\text { Consumers' psychological assessment of their post-shopping } \\
\text { experience compared with pre-shopping expectations }\end{array}$ & Oliver (1980) \\
\hline Repurchase intentions & RI & $\begin{array}{l}\text { Consumers' willingness to patronize the same live streamer in } \\
\text { the future }\end{array}$ & Guo Bin (2019) \\
\hline
\end{tabular}

Table 2. Variable measurement items in differnt studies

\begin{tabular}{|c|c|c|c|}
\hline Name and code & $\begin{array}{l}\text { Measurement } \\
\text { item code }\end{array}$ & Measurement item content & Reference \\
\hline $\begin{array}{l}\text { Perceived product } \\
\text { quality (PPQ) }\end{array}$ & $\begin{array}{l}\text { Q1 } \\
\text { Q2 }\end{array}$ & $\begin{array}{l}\text { The product I bought from the live streamer has good quality. } \\
\text { I am satisfied with the quality of products I bought from the live } \\
\text { streamer. } \\
\text { The quality of products purchased on the live streamer's channel meets } \\
\text { my expectations. }\end{array}$ & $\begin{array}{l}\text { Brucks et al. (2000), } \\
\text { Fang et al. (2016), Kim } \\
\text { et al. (2012). }\end{array}$ \\
\hline $\begin{array}{l}\text { Perceived } \\
\text { entertainment } \\
\text { (PE) } \\
\text { Perceived } \\
\text { discount (PD) }\end{array}$ & $\begin{array}{l}\text { Q4 } \\
\text { Q5 } \\
\text { Q6 } \\
\text { Q7 } \\
\text { Q8 }\end{array}$ & $\begin{array}{l}\text { I feel happy to shop from the live streamer. } \\
\text { I felt time passed quickly while I was shopping from the live streamer. } \\
\text { I think it is interesting to shop from the live streamer. } \\
\text { The live streamer offers great benefits such as big discounts and lots of } \\
\text { gifts. } \\
\text { I can enjoy higher discounts or more gifts from the live streamer than } \\
\text { from other shopping channels. } \\
\text { I think shopping from the live streamer is more cost-effective than from } \\
\text { other shopping channels. }\end{array}$ & $\begin{array}{l}\text { Davis et al. (1989), } \\
\text { Tsang et al. (2004), } \\
\text { Moon and Kim (2001). } \\
\text { Berkowitz and Walton } \\
\text { (1980), Liang and Huang } \\
\text { (1998). }\end{array}$ \\
\hline $\begin{array}{l}\text { Perceived } \\
\text { interactivity (PI) }\end{array}$ & $\begin{array}{l}\text { Q10 } \\
\text { Q11 }\end{array}$ & $\begin{array}{l}\text { I feel like having face-to-face communication with the streamer while } \\
\text { shopping from him/her. } \\
\text { I can interact with the live streamer via bullet comments while } \\
\text { shopping from him/her. } \\
\text { The live streamer often interacts with the audience during live streams. }\end{array}$ & Chen and Lin (2018). \\
\hline $\begin{array}{l}\text { Perceived } \\
\text { professionalism } \\
\text { (PP) }\end{array}$ & Q14 & $\begin{array}{l}\text { Equipped with extensive experience in using the products he/she is } \\
\text { promoting, the live streamer can give me correct instructions on how to } \\
\text { use the products. } \\
\text { The live streamer can help me buy the right product with his/her great } \\
\text { knowledge about the product features and target users. } \\
\text { The live streamer knows well about product properties and usage. } \\
\text { Thus, it is all right to use the products as he/she told me. }\end{array}$ & $\begin{array}{l}\text { Bickart and Schindler } \\
\text { (2001), Bansal and } \\
\text { Voyer (2000). }\end{array}$ \\
\hline $\begin{array}{l}\text { Perceived } \\
\text { similarity (PS) }\end{array}$ & $\begin{array}{l}\text { Q16 } \\
\text { Q17 } \\
\text { Q18 }\end{array}$ & $\begin{array}{l}\text { I think the live streamer and I share similar product preferences. } \\
\text { I think the live streamer and I have the same taste and style in products. } \\
\text { I think the live streamer and I see eye to eye on products. }\end{array}$ & Gilly et al. (1998). \\
\hline $\begin{array}{l}\text { Consumer } \\
\text { satisfaction (CS) }\end{array}$ & M1 & $\begin{array}{l}\text { Overall, I am satisfied with my experience in shopping from the live } \\
\text { streamer. } \\
\text { Overall, I think my experience in shopping from the live streamer is } \\
\text { good. } \\
\text { I believe that shopping from the live streamer is a wise decision. }\end{array}$ & $\begin{array}{l}\text { Bhattacherjee (2001), } \\
\text { Janda et al. (2002), Lee } \\
\text { and Chung (2009). }\end{array}$ \\
\hline $\begin{array}{l}\text { Repurchase } \\
\text { intentions (RI) }\end{array}$ & $\begin{array}{l}\text { A1 } \\
\text { A2 } \\
\text { A3 }\end{array}$ & $\begin{array}{l}\text { I will buy from the live streamer again. } \\
\text { I am willing to buy more from the live streamer. } \\
\text { I think I may become a regular/loyal customer of the live streamer. }\end{array}$ & $\begin{array}{l}\text { Parasuraman et al. } \\
\text { (2005), Chiu et al. } \\
\text { (2013), Janda et al. } \\
\text { (2002) }\end{array}$ \\
\hline
\end{tabular}




\subsection{Data Collection}

After the preliminary design, the questionnaire for this study was not put into immediately use for data collection. Instead, it was tweaked through interviews with consumers who had shopped in e-commerce live streams before, a move that aims to ensure all measurement items are reasonable and easily understand. The questionnaire consists of two parts. The first part mainly aims to collect basic information of respondents, namely, gender, age, educational level, occupation, average monthly income, and average monthly online shopping frequency. In addition, this part contains two basic questions, namely, "Have you ever watched e-commerce live streams?" and "Have you ever bought anything in e-commerce live streams?" The second part is designed to survey consumer repurchase intentions in e-commerce live streams. With 24 measurement items in total, this part uses a 5-point Likert scale to measure the eight variables of this study.

After the questionnaire was finalized, the study progressed to the stage of data collection. For the convenience of distributing and collecting questionnaires under the cloud of the COVID-19 pandemic, the questionnaire was published on WJX.CN, an online questionnaire survey platform, to gather the data for empirical analysis. After that, the authors invited respondents via online channels such as QQ and WeChat to take the survey. In the end, a total of 534 questionnaires were collected.

Invalid questionnaires were deleted before the data analysis began. Some questionnaires were deemed invalid on the grounds that: 1) Respondents had the same answer to all the measurement items in the second part of the questionnaire where a 5-point Likert scale is employed; 2) respondents' answers were inconsistent; 3) respondents gave a "no" answer to either of the two basic questions in the first part of the questionnaire; 4) respondents chose " $<1$ " for the sixth measurement item, i.e., average monthly online shopping frequency. Based on the above standards, 82 invalid questionnaires were deleted, leaving 452 valid ones in total. In other words, $84.64 \%$ of collected questionnaires are valid.

\subsection{Descriptive Statistics}

This study used descriptive statistics to analyze questionnaires in the light of respondents' basic information, so as to sort out the valid samples. The statistic results are shown in Table 3.

Table 3. Basic information of valid questionnaire respondents

\begin{tabular}{|c|c|c|c|}
\hline Item & Cohort & Count & Ratio \\
\hline \multirow[t]{2}{*}{ Gender } & Male & 179 & $39.60 \%$ \\
\hline & Female & 273 & $60.40 \%$ \\
\hline \multirow[t]{5}{*}{ Age } & $<18$ & 16 & $3.54 \%$ \\
\hline & $18-25$ & 182 & $40.27 \%$ \\
\hline & $26-30$ & 185 & $40.93 \%$ \\
\hline & $31-40$ & 62 & $13.72 \%$ \\
\hline & $>40$ & 7 & $1.55 \%$ \\
\hline \multirow[t]{4}{*}{ Educational level } & High school degree or below & 91 & $20.13 \%$ \\
\hline & Associate degree & 135 & $29.87 \%$ \\
\hline & Bachelor's degree & 140 & $30.97 \%$ \\
\hline & Master's degree or higher & 86 & $19.03 \%$ \\
\hline \multirow[t]{6}{*}{ Occupation } & Student & 120 & $26.55 \%$ \\
\hline & Public officer (civil servant or public institution staff member) & 33 & $7.30 \%$ \\
\hline & Employee & 247 & $54.65 \%$ \\
\hline & Self-employed people & 28 & $6.19 \%$ \\
\hline & Freelancer & 2 & $0.44 \%$ \\
\hline & Other & 22 & $4.87 \%$ \\
\hline \multirow[t]{6}{*}{ Average monthly income } & $<$ RMB 1,000 & 32 & $7.08 \%$ \\
\hline & RMB $1,000-3,000$ & 64 & $14.16 \%$ \\
\hline & RMB 3,001-5,000 & 97 & $21.46 \%$ \\
\hline & RMB 5,001-8,000 & 203 & $44.91 \%$ \\
\hline & RMB $8,001-12,000$ & 49 & $10.84 \%$ \\
\hline & $>$ RMB 12,000 & 7 & $1.55 \%$ \\
\hline \multirow{5}{*}{$\begin{array}{l}\text { Average monthly online } \\
\text { shopping frequency }\end{array}$} & $<1$ & 0 & $0.00 \%$ \\
\hline & $1-3$ & 86 & $19.03 \%$ \\
\hline & $4-7$ & 186 & $41.15 \%$ \\
\hline & $8-10$ & 131 & $28.98 \%$ \\
\hline & $>10$ & 49 & $10.84 \%$ \\
\hline
\end{tabular}


As shown in Table 3, the respondents were predominantly women $(60.40 \%)$, with a male-female ratio of about 4:6. Most of them were aged $18-25$ and $26-30$, accounting for $40.27 \%$ and $40.93 \%$ respectively. In terms of educational level, respondents who held an associate degree or a bachelor's degree account for $29.87 \%$ and $30.97 \%$ respectively. In addition, $54.65 \%$ respondents were employees and $44.91 \%$ earned RMB 5,001-8,000 a month. With regard to online shopping frequencies, $41.15 \%$ of respondents shopped 4-7 times a month and $28.98 \%$ did $8-10$ times a month. Overall, the respondents were widely distributed.

\subsection{Reliability and Validity Assessment}

Taking full account of the reliability assessment measures in previous studies, the authors adopted Cronbach's alpha to assess the reliability of the sample data. The results are listed in Table 4. The Cronbach's alpha values of the overall questionnaire and various research variables are all higher than the acceptable minimum coefficient of 0.7. This means that both the questionnaire and the sample data are reliable in general.

Table 4. Reliability assessment results

\begin{tabular}{llll}
\hline Variable & $\begin{array}{l}\text { Quantity of } \\
\text { measurement items }\end{array}$ & Source of measurement items & $\begin{array}{l}\text { Cronbach's alpha } \\
\text { value }\end{array}$ \\
\hline PPQ & 3 & Brucks et al. (2000), Fang et al. (2016), Kim et al. (2012). & 0.870 \\
PE & 3 & Davis et al. (1989), Tsang et al. (2004), Moon and Kim (2001). & 0.837 \\
PD & 3 & Berkowitz and Walton (1980), Liang and Huang (1998). & 0.846 \\
PI & 3 & Chen and Lin (2018). & 0.781 \\
PP & 3 & Bickart and Schindler (2001), Bansal and Voyer (2000). & 0.845 \\
PS & 3 & Gilly et al. (1998). & 0.861 \\
CS & 3 & Bhattacherjee (2001), Janda et al. (2002), Lee and Chung (2009). & 0.891 \\
RI & 3 & Parasuraman et al. (2005), Chiu et al. (2013), Janda et al. (2002) & 0.865 \\
Overall & 24 & & 0.904 \\
\hline
\end{tabular}

Generally, a good questionnaire is subject to the content and construct validity test. In terms of content validity, all measurement items in this study come from scales that have been used and tested by scholars in previous studies and have been revised based on interviews before the questionnaire is finalized. Therefore, this questionnaire can be deemed to have established a good content validity. The construct validity consists of convergent validity and divergent validity. This study assesses the construct validity of the questionnaire by confirmatory factor analysis (CFA), and the results are shown in Tables 5, 6, and 7. Table 5 shows that the model fit indices are all within the range of recommended value, indicating a good fitting model. Table 6 illustrates a good convergent validity as the normalized factor loadings and composite reliability $(\mathrm{CR})$ values all exceed 0.6 and the average variances extracted (AVE) are all higher than 0.5 . Table 7 indicates a good divergent validity: Values on the diagonal line are the square root of AVE of various variables, which are all greater than the correlation coefficients between the variable and all other variables. Based on the above analysis, it can be concluded that the questionnaire is valid.

Table 5. CFA model fit indices

\begin{tabular}{llll}
\hline Fit index & Recommended value & Actual value & Model fit \\
\hline Chi square/degree of freedom (DF) ratio & $1-3$ & 1.115 & Ideal \\
RMSEA & $<0.08$ & 0.016 & Ideal \\
GFI & $>0.9$ & 0.956 & Ideal \\
CFI & $>0.9$ & 0.996 & Ideal \\
TLI & $>0.9$ & 0.995 & Ideal \\
IFI & $>0.9$ & 0.996 & Ideal \\
\hline
\end{tabular}


Table 6. Convergent validity results

\begin{tabular}{|c|c|c|c|c|}
\hline Factor & Measurement item & Normalized factor loading & $\mathrm{CR}$ & AVE \\
\hline \multirow[t]{3}{*}{ PPQ } & Q1 & 0.816 & 0.871 & 0.693 \\
\hline & Q2 & 0.798 & & \\
\hline & Q3 & 0.881 & & \\
\hline \multirow[t]{3}{*}{ PE } & Q4 & 0.779 & 0.839 & 0.634 \\
\hline & Q5 & 0.776 & & \\
\hline & Q6 & 0.833 & & \\
\hline \multirow[t]{3}{*}{ PD } & Q7 & 0.859 & 0.850 & 0.654 \\
\hline & Q8 & 0.771 & & \\
\hline & Q9 & 0.793 & & \\
\hline \multirow[t]{3}{*}{ PI } & Q10 & 0.711 & 0.782 & 0.545 \\
\hline & Q11 & 0.776 & & \\
\hline & Q12 & 0.727 & & \\
\hline \multirow[t]{3}{*}{ PP } & Q13 & 0.767 & 0.845 & 0.646 \\
\hline & Q14 & 0.790 & & \\
\hline & Q15 & 0.852 & & \\
\hline \multirow[t]{3}{*}{ PS } & Q16 & 0.844 & 0.861 & 0.675 \\
\hline & Q17 & 0.772 & & \\
\hline & Q18 & 0.846 & & \\
\hline \multirow[t]{3}{*}{ CS } & M1 & 0.883 & 0.897 & 0.743 \\
\hline & M2 & 0.835 & & \\
\hline & M3 & 0.867 & & \\
\hline \multirow[t]{3}{*}{ RI } & A1 & 0.821 & 0.866 & 0.683 \\
\hline & $\mathrm{A} 2$ & 0.794 & & \\
\hline & $\mathrm{A} 3$ & 0.862 & & \\
\hline
\end{tabular}

Table 7. Divergent validity results

\begin{tabular}{lllllllll}
\hline & RI & CS & PS & PP & PI & PD & PE & PPQ \\
\hline RI & 0.826 & & & & & & & \\
CS & 0.684 & 0.862 & & & & & & \\
PS & 0.431 & 0.405 & 0.821 & & & & & \\
PP & 0.396 & 0.595 & 0.371 & 0.804 & & & & \\
PI & 0.381 & 0.561 & 0.447 & 0.564 & 0.739 & & & \\
PD & 0.325 & 0.438 & 0.260 & 0.302 & 0.193 & 0.809 & & \\
PE & 0.419 & 0.416 & 0.226 & 0.350 & 0.405 & 0.279 & 0.796 & 0.246 \\
PPQ & 0.281 & 0.468 & 0.097 & 0.136 & 0.304 & 0.542 & 0.2432 \\
\hline
\end{tabular}

\subsection{Hypothesis Examination}

\subsubsection{Path Examination}

After the validation of the reliability and validity of the questionnaire, the authors used the structural equation modeling (SEM) with analysis of moment structures (AMOS) to test the research model, in a bid to provide a basis for determining whether the research hypotheses proposed are tenable. Test results in Tables 8 and 9 show the full model fit indices correspond to the recommended value, indicating that the model fits well with the data. In addition, the $\mathrm{P}$ value of eight out of the 13 paths is less than 0.05 , indicating that these eight paths are significant. Moreover, the path coefficients of these eight paths are all positive. Therefore, H2, H6, H7, H8, H10, $\mathrm{H} 11, \mathrm{H} 12$, and $\mathrm{H} 13$ are tenable, whereas $\mathrm{H} 1, \mathrm{H} 3, \mathrm{H} 4, \mathrm{H} 5, \mathrm{H} 9$ are untenable.

Table 8. Full model fit indices

\begin{tabular}{llll}
\hline Fit index & Recommended value & Actual value & Model fit \\
\cline { 2 - 4 } Chi square/degree of freedom (DF) ratio & $1-3$ & 1.115 & Ideal \\
RMSEA & $<0.08$ & 0.016 & Ideal \\
GFI & $>0.9$ & 0.956 & Ideal \\
CFI & $>0.9$ & 0.996 & Ideal \\
TLI & $>0.9$ & 0.995 & Ideal \\
IFI & $>0.9$ & 0.996 & Ideal \\
\hline
\end{tabular}


Table 9. Parameter estimates of full model variable paths

\begin{tabular}{|c|c|c|c|c|c|}
\hline Path & $\begin{array}{l}\text { Non-standardized } \\
\text { parameter value }\end{array}$ & Standard error & $\mathrm{T}$ value & P value & $\begin{array}{l}\text { Standardized parameter } \\
\text { value (path coefficient) }\end{array}$ \\
\hline CS<---PPQ & 0.298 & 0.057 & 5.265 & $<0.001$ & 0.291 \\
\hline $\mathrm{CS}<---\mathrm{PE}$ & 0.112 & 0.049 & 2.253 & 0.024 & 0.105 \\
\hline CS $<---P D$ & 0.079 & 0.056 & 1.401 & 0.161 & 0.078 \\
\hline CS<---PI & 0.196 & 0.084 & 2.330 & 0.020 & 0.153 \\
\hline $\mathrm{CS}<---\mathrm{PP}$ & 0.388 & 0.063 & 6.178 & $<0.001$ & 0.360 \\
\hline CS $<---P S$ & 0.125 & 0.046 & 2.713 & 0.007 & 0.131 \\
\hline $\mathrm{RI}<---\mathrm{CS}$ & 0.633 & 0.074 & 8.542 & $<0.001$ & 0.636 \\
\hline RI<---PPQ & -0.050 & 0.064 & -0.786 & 0.432 & -0.049 \\
\hline $\mathrm{RI}<---\mathrm{PE}$ & 0.187 & 0.054 & 3.459 & $<0.001$ & 0.177 \\
\hline RI<---PD & 0.009 & 0.060 & 0.144 & 0.886 & 0.009 \\
\hline RI $<---P I$ & -0.109 & 0.091 & -1.198 & 0.231 & -0.085 \\
\hline RI<---PP & -0.071 & 0.071 & -0.990 & 0.322 & -0.066 \\
\hline RI<---PS & 0.190 & 0.051 & 3.747 & $<0.001$ & 0.199 \\
\hline
\end{tabular}

\subsubsection{Mediation Effect Assessment}

This study adopts bootstrapping to test the mediation effect of consumer satisfaction. The sampling was done 5,000 times and 95\% confidence interval was chosen. The test results are shown in Table 10. Based on whether the $95 \%$ bootstrap confidence interval for each variable's indirect effect on repurchase intentions includes 0 , it can be concluded that consumer satisfaction has a significant mediation effect on the relationship between PPQ/PE/PI/PP/PS and repurchase intentions. Thus, H14, H15, H17, H18, and H19 are tenable, whereas H16 is untenable due to the insignificant mediation effect it has on the relationship between PD and repurchase intentions. Furthermore, based on whether the $95 \%$ bootstrap confidence interval for each variable's direct effect on repurchase intentions contains 0 , it can be concluded that consumer satisfaction fully mediates the relationship between $\mathrm{PPQ} / \mathrm{PI} / \mathrm{PP}$ and repurchase intentions, and that it partially mediates the relationship between $\mathrm{PE} / \mathrm{PS}$ and repurchase intentions.

Table 10. Results of consumer satisfaction mediation effect assessment

\begin{tabular}{llllll}
\hline $\begin{array}{l}\text { Independent } \\
\text { variable }\end{array}$ & Effect & $\begin{array}{l}\text { Standardized } \\
\text { effect size }\end{array}$ & $\begin{array}{l}\text { Bootstrap } \\
\text { standard error }\end{array}$ & $\begin{array}{l}95 \% \text { bootstrap confidence interval } \\
\text { Lower confidence limit }\end{array}$ & \begin{tabular}{l} 
Upper confidence limit \\
\hline PPQ
\end{tabular} \\
& Gross effect & 0.136 & 0.070 & -0.007 & 0.273 \\
& Direct effect & -0.049 & 0.069 & -0.196 & 0.082 \\
PE & Indirect effect & 0.185 & 0.041 & 0.118 & 0.281 \\
& Gross effect & 0.244 & 0.056 & 0.135 & 0.378 \\
& Direct effect & 0.177 & 0.051 & 0.082 & 0.298 \\
PD & Indirect effect & 0.067 & 0.032 & 0.006 & 0.143 \\
& Gross effect & 0.058 & 0.073 & -0.085 & 0.211 \\
& Direct effect & 0.009 & 0.067 & -0.121 & 0.148 \\
PI & Indirect effect & 0.050 & 0.041 & -0.028 & 0.138 \\
& Gross effect & 0.012 & 0.078 & -0.186 & 0.206 \\
& Direct effect & -0.085 & 0.073 & -0.302 & 0.069 \\
PP & Indirect effect & 0.097 & 0.041 & 0.032 & 0.246 \\
& Gross effect & 0.163 & 0.074 & 0.019 & 0.331 \\
& Direct effect & -0.066 & 0.074 & -0.234 & 0.079 \\
PS & Indirect effect & 0.229 & 0.046 & 0.154 & 0.358 \\
& Gross effect & 0.282 & 0.056 & 0.161 & 0.380 \\
& Direct effect & 0.199 & 0.053 & 0.090 & 0.289 \\
& Indirect effect & 0.083 & 0.032 & 0.021 & 0.147 \\
\hline
\end{tabular}

\subsubsection{Model Modification}

The insignificant paths in the initial model were removed and the indices of the modified model are listed in Tables 11 and 12. The modified model is good-fitting as all paths are significant and all path coefficients are positive. The research model constructed after the empirical testing is shown as Fig.2. 
Table 11. Modified model fit indices

\begin{tabular}{llll}
\hline Fit index & Recommended value & Actual value & Model fit \\
\hline Chi square/degree of freedom (DF) ratio & $1-3$ & 1.153 & Ideal \\
RMSEA & $<0.08$ & 0.018 & Ideal \\
GFI & $>0.9$ & 0.960 & Ideal \\
CFI & $>0.9$ & 0.995 & Ideal \\
TLI & $>0.9$ & 0.994 & Ideal \\
IFI & $>0.9$ & 0.995 & Ideal \\
\hline
\end{tabular}

Table 12. Parameter estimates of modified model variable paths

\begin{tabular}{|c|c|c|c|c|c|}
\hline Path & $\begin{array}{l}\text { Non-standardized } \\
\text { parameter value }\end{array}$ & Standard error & T value & P value & $\begin{array}{l}\text { Standardized parameter value } \\
\text { (path coefficient) }\end{array}$ \\
\hline CS<---PPQ & 0.339 & 0.045 & 7.482 & $<0.001$ & 0.332 \\
\hline CS $<---P E$ & 0.126 & 0.049 & 2.542 & 0.011 & 0.118 \\
\hline CS $<---P I$ & 0.162 & 0.081 & 2.012 & 0.044 & 0.126 \\
\hline CS<---PP & 0.408 & 0.060 & 6.749 & $<0.001$ & 0.378 \\
\hline CS $<---P S$ & 0.146 & 0.045 & 3.253 & 0.001 & 0.152 \\
\hline RI<---PE & 0.158 & 0.051 & 3.079 & 0.002 & 0.150 \\
\hline RI<---PS & 0.167 & 0.046 & 3.667 & $<0.001$ & 0.174 \\
\hline $\mathrm{RI}<---\mathrm{CS}$ & 0.539 & 0.054 & 9.954 & $<0.001$ & 0.543 \\
\hline
\end{tabular}

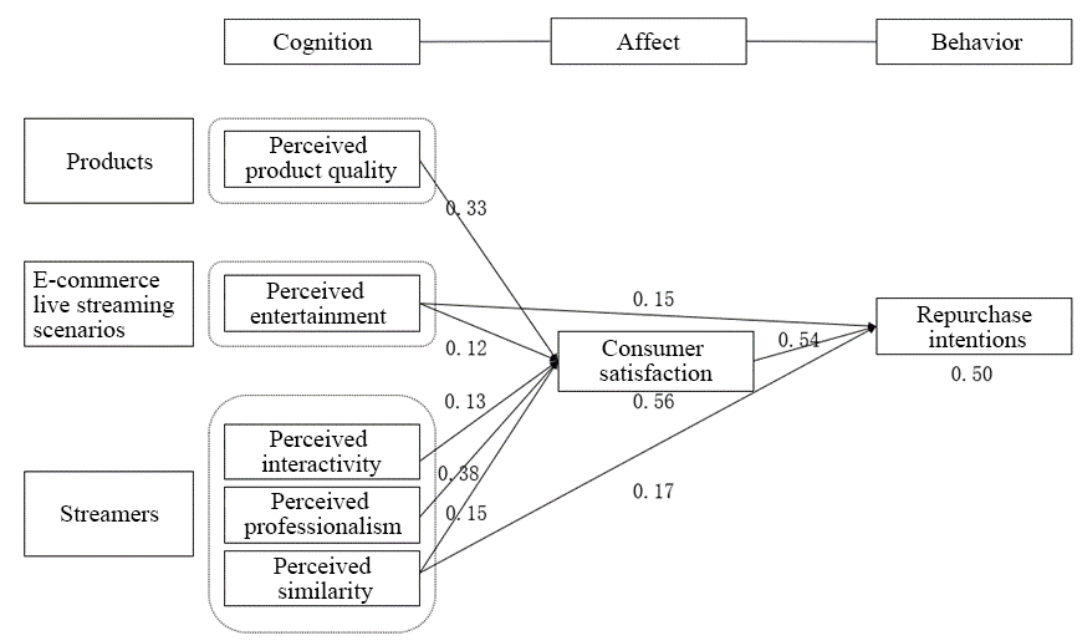

Figure 2. Research model after empirical testing

\subsubsection{Hypothesis Testing Results}

Based on the empirical analysis, the hypothesis testing results are presented in Table 13. 
Table 13. Hypothesis testing results

\begin{tabular}{|c|c|c|}
\hline Hypothesis code & Hypothesis & Testing result \\
\hline $\mathrm{H} 1$ & Perceived product quality has a positive impact on repurchase intentions. & Untenable \\
\hline $\mathrm{H} 2$ & Perceived entertainment has a positive impact on repurchase intentions. & Tenable \\
\hline $\mathrm{H} 3$ & Perceived discount has a positive impact on repurchase intentions. & Untenable \\
\hline $\mathrm{H} 4$ & Perceived interactivity has a positive impact on repurchase intentions. & Untenable \\
\hline $\mathrm{H} 5$ & Perceived professionalism has a positive impact on repurchase intentions. & Untenable \\
\hline H6 & Perceived similarity has a positive impact on repurchase intentions. & Tenable \\
\hline $\mathrm{H} 7$ & Perceived product quality has a positive impact on consumer satisfaction. & Tenable \\
\hline $\mathrm{H} 8$ & Perceived entertainment has a positive impact on consumer satisfaction. & Tenable \\
\hline H9 & Perceived discount has a positive impact on consumer satisfaction. & Untenable \\
\hline H10 & Perceived interactivity has a positive impact on consumer satisfaction. & Tenable \\
\hline H11 & Perceived professionalism has a positive impact on consumer satisfaction. & Tenable \\
\hline $\mathrm{H} 12$ & Perceived similarity has a positive impact on consumer satisfaction. & Tenable \\
\hline H13 & Consumer satisfaction has a positive impact on repurchase intentions. & Tenable \\
\hline H14 & $\begin{array}{l}\text { Consumer satisfaction mediates the relationship between perceived product quality and } \\
\text { repurchase intentions. }\end{array}$ & Tenable \\
\hline H15 & $\begin{array}{l}\text { Consumer satisfaction mediates the relationship between perceived entertainment and } \\
\text { repurchase intentions. }\end{array}$ & Tenable \\
\hline H16 & $\begin{array}{l}\text { Consumer satisfaction mediates the relationship between perceived discount and } \\
\text { repurchase intentions. }\end{array}$ & Untenable \\
\hline H17 & $\begin{array}{l}\text { Consumer satisfaction mediates the relationship between perceived interactivity and } \\
\text { repurchase intentions. }\end{array}$ & Tenable \\
\hline H18 & $\begin{array}{l}\text { Consumer satisfaction mediates the relationship between perceived professionalism } \\
\text { and repurchase intentions. }\end{array}$ & Tenable \\
\hline H19 & $\begin{array}{l}\text { Consumer satisfaction mediates the relationship between perceived similarity and } \\
\text { repurchase intentions. }\end{array}$ & Tenable \\
\hline
\end{tabular}

\section{Dicussion}

\subsection{Conclusion and Suggestion}

This study probes into how e-commerce live streaming affects consumer repurchase intentions and what role consumer satisfaction plays in this process based on factors of products (perceived product quality), e-commerce live streaming scenarios (perceived entertainment and perceived discount) and streamers (perceived interactivity, perceived professionalism, and perceived similarity). The authors reach the following conclusions based on the empirical analysis results:

1) In terms of products, perceived product quality positively and indirectly affects consumer repurchase intentions, and consumer satisfaction fully mediates this relationship.

2) In terms of e-commerce live streaming scenarios, perceived entertainment has a significant positive effect on consumer repurchase intentions, and consumer satisfaction partially mediates this relationship. Perceived discount has no influence on consumer repurchase intentions.

3) In terms of streamers, perceived interactivity and perceived professionalism positively and indirectly affect consumer repurchase intentions, and consumer satisfaction fully mediates this relationship. Perceived similarity has a significant positive effect on consumer repurchase intentions, and consumer satisfaction partially mediates this relationship.

Based on these conclusions, the study proposes five suggestions for live streamers on how to increase consumers' repeat purchase rates and foster customer loyalty:

Carry out a strict product selection process and strengthen the quality control review. Streamers have to be careful about the products they are promoting and be steadfast against shoddy goods at the very beginning. Once they have selected the products, they should keep paying great attention to the product quality in the long run.

Create an interesting and appealing live streaming environment. Featured by scenario-based selling, e-commerce live streams need to be enlivened by specific scenarios. Therefore, streamers should select different scenarios for different themes to enhance user stickiness and foster customer loyalty.

Develop innovative interactions with consumers. Streamers should have a higher awareness of interaction with consumers during live streams, as interactions can help them better understand and meet consumers' needs, thus increasing consumers' sense of participation and empathy. As to how to interact with their audience, streamers 
can put questions to consumers by, among other things, holding prize-giving quizzes. In addition, VR technology can be good empowerment for interactions with consumers.

Enhance professional knowledge about products and strive to be an industry expert. Streamers should make great efforts in acquiring the necessary knowledge related to the products they are marketing, including potential product problems and corresponding solutions.

Gain insights into consumer groups and create an attractive public persona. Streamers should have an in-depth analysis of consumer groups they are targeting, in a bid to understand their basic characteristics such as personality, style, taste, product preferences, and values. Based on these findings, streamers should craft a charming public persona that suits their own characters and maintain their public image.

\subsection{Limitation and Future Research}

While this research provides theoretical and managerial implications, it also has certain limitations, to be further studied and improved. First of all, this study focuses on factors of products, e-commerce live streaming scenarios, and streamers. It is a pity that there is no survey on the product category in the questionnaire design. Female consumers tend to be more interested in the live broadcast of beauty make-up and dressing, and male consumers are more interested in the live broadcast of science and technology or online games. In future research, we can start with different product categories and measure the effect of the live streaming of e-commerce on consumers' repeated purchase intention. Secondly, for individual characteristics (sex, age, income, etc) as well as streamers' characteristics (such as popularity), we can try to test the moderating effect of these factors, in-depth study of the demographic variables in addition to live e-commerce on the impact of consumer repeated purchase intention differences.

\section{References}

Bansal, H. S., \& Voyer, P. A. (2000). Word-of-Mouth Processes within a Services Purchase Decision Context. Journal of Service Research, 3(2), 166-177. https://doi.org/10.1177/109467050032005

Berkowitz, E. N., \& Walton, J. R. (1980). Contextual Influences on Consumer Price Responses: An Experimental Analysis. Journal of Marketing Research, 17(3), 349-358. https://doi.org/10.1177/002224378001700308

Bhattacherjee, A. (2001). Understanding information systems continuance: An expectation-confirmation model. Mis Quarterly, 25(3), 351-370. https://doi.org/10.2307/3250921

Bickart, B., \& Schindler, R. M. (2001). Internet forums as influential sources of consumer information. Journal of Interactive Marketing, 15(3), 31-40. https://doi.org/10.1002/dir.1014

Bolton, R. N., \& Drew, J. H. (1991). A Longitudinal Analysis of the Impact of Service Changes on Customer Attitudes. Journal of Marketing, 55(1), 1-9. https://doi.org/10.1177/002224299105500101

Bouwman, H., Carlsson, C., Molina-Castillo, F. J., \& Walden, P. (2006). Barriers and drivers in the adoption of current and future mobile services in Finland. Telematics and Informatics, 24(2), 145-160. https://doi.org/10.1016/j.tele.2006.08.001

Brucks, M., Zeithaml, V. A., \& Naylor, G. (2000). Price and brand name as indicators of quality dimensions for consumer durables. Journal of the Academy of Marketing Science, 28(3), 359-374. https://doi.org/10.1177/0092070300283005

Cardozo, R. N. (1965). An Experimental Study of Customer Effort, Expectation, and Satisfaction. Journal of Marketing Research, 2(3), 244-249. https://doi.org/10.1177/002224376500200303

Chan, K. K., \& Misra, S. (1990). Characteristics of the Opinion Leader: A New Dimension. Journal of Advertising, 19(3), 53-60. https://doi.org/10.1080/00913367.1990.10673192

Chang, M. K., \& Cheung, W. (2001). Determinants of the intention to use Internet/WWW at work: A confirmatory study. Information \& Management, $39(1), \quad 1-14$. https://doi.org/10.1016/S0378-7206(01)00075-1

Chen, C.-C., \& Lin, Y.-C. (2018). What drives live-stream usage intention? The perspectives of flow, entertainment, social interaction, and endorsement. Pergamon, 35(1), 293-303. https://doi.org/10.1016/j.tele.2017.12.003

Chiu, C.-M., Fang, Y.-H., Cheng, H.-L., \& Yen, C. (2013). On online repurchase intentions: Antecedents and the moderating role of switching cost. Human Systems Management, 32(4), 283-296. https://doi.org/10.3233/HSM-130796 
Chiu, C. M., Hsu, M. H., Sun, S. Y., Lin, T. C., \& Sun, P. C. (2005). Usability, quality, value and e-learning continuance decisions. Computers \& Education, 42(5), 399-416. https://doi.org/10.1016/j.compedu.2004.06.001

Davis, F. D., Bagozzi, R. P., \& Warshaw, P. R. (1989). User Acceptance of Computer Technology: A Comparison of Two Theoretical Models. Management Science, 35(8), 982-1003. https://doi.org/10.1287/mnsc.35.8.982

Fang, J., George, B., Shao, Y., \& Wen, C. (2016). Affective and cognitive factors influencing repeat buying in e-commerce. Electronic Commerce Research and Applications, 44-55. https://doi.org/10.1016/j.elerap.2016.08.001

Ghose, S., \& Dou, W. Y. (1998). Interactive functions and their impacts on the appeal of Internet Presence Sites. Journal of Advertising Research, 38(2), 29-43.

Gilly, M. C., Graham, J. L., Wolfinbarger, M. F., \& Yale, L. J. (1998). A dyadic study of interpersonal information search. Journal of the Academy of Marketing Science, 26(2), 83-100. https://doi.org/10.1177/0092070398262001

Hsu, J. S.-C., Lin, T.-C., Fu, T.-W., \& Hung, Y.-W. (2015). The effect of unexpected features on app users' continuance intention. Electronic Commerce Research and Applications, 14(6), 418-430. https://doi.org/10.1016/j.elerap.2015.06.003

Janda, S., Trocchia, P. J., \& Gwinner, K. P. (2002). Consumer perceptions of Internet retail service quality. International Journal of Service Industry Management, 13(5), 412-431. https://doi.org/10.1108/09564230210447913

Kim, B. (2010). An empirical investigation of mobile data service continuance: Incorporating the theory of planned behavior into the expectation-confirmation model. Expert Systems with Applications, 37(10), 7033-7039. https://doi.org/10.1016/j.eswa.2010.03.015

Kim, C., Galliers, R. D., Shin, N., Ryoo, J.-H., \& Kim, J. (2012). Factors influencing Internet shopping value and customer repurchase intention. Electronic Commerce Research and Applications, 11(4), 374-387. https://doi.org/10.1016/j.elerap.2012.04.002

Kim, H. M., \& Kramer, T. (2006). The moderating effects of need for cognition and cognitive effort on responses to multi-dimensional prices. Marketing Letters, 17(3), 193-203. https://doi.org/10.1007/s11002-006-5928-2

Kim, S. H. (2008). Moderating effects of Job Relevance and Experience on mobile wireless technology acceptance: Adoption of a smartphone by individuals. Information \& Management, 45(6), 387-393. https://doi.org/10.1016/j.im.2008.05.002

Lee, K. C., \& Chung, N. (2009). Understanding factors affecting trust in and satisfaction with mobile banking in Korea: A modified DeLone and McLean's model perspective. Interacting with Computers, 21(5), 385-392. https://doi.org/10.1016/j.intcom.2009.06.004

Liang, T.-P., \& Huang, J.-S. (1998). An empirical study on consumer acceptance of products in electronic markets: A transaction cost model. Decision Support Systems, 24(1), 29-43. https://doi.org/10.1016/S0167-9236(98)00061-X

Lin, C. S., Wu, S., \& Tsai, R. J. (2004). Integrating perceived playfulness into expectation-confirmation model for web portal context. Information \& Management, 42(5), 683-693. https://doi.org/10.1016/j.im.2004.04.003

Ling, K. C., Chai, L. T., \& Piew, T. H. (2010). The effect of Shopping Orientations, Online Trust and Prior Online Purchase Experience toward Customers' Online Purchase Intention. International Business Research, 3(3), 63-76. https://doi.org/10.5539/ibr.v3n3p63

Moon, J.-W., \& Kim, Y.-G. (2001). Extending the TAM for a World-Wide-Web context. Information \& Management, 38(4), 217-230. https://doi.org/10.1016/S0378-7206(00)00061-6

Murgulets, L., Eklöf, J., Dukeov, I., \& Selivanova, I. (2001). Customer satisfaction and retention in transition economies. Total Quality Management, 12(7), 1037-1046. https://doi.org/10.1080/09544120120096215

Oliver, R. L. (1980). A Cognitive Model of the Antecedents and Consequences of Satisfaction Decisions. Journal of Marketing Research, 17(4), 460-469. https://doi.org/10.1177/002224378001700405

Parasuraman, A., Zeithaml, V. A., \& Malhotra, A. (2005). E-S-QUAL-A multiple-item scale for assessing electronic service quality. Journal of Service Research, 7(3), 213-233. 
https://doi.org/10.1177/1094670504271156

Patterson, P. G., \& Spreng, R. A. (1997). Modelling the relationship between perceived value, satisfaction and repurchase intentions in a business-to-business, services context: An empirical examination. International Journal of Service Industry Management, 8(5), 414-434. https://doi.org/10.1108/09564239710189835

Rogers, E. M., \& Bhowmik, D. K. (1970). Homophily-Heterophily: Relational Concepts for Communication Research. The Public Opinion Quarterly, 34(4), 523-538. https://doi.org/10.1086/267838

Rosenberg, M. J., \& Hovland, C. I. (1960). Cognitive, affective, and behavioral components of attitudes. Attitude Organization and Change, 1-14.

Ruef, M., Aldrich, H. E., \& Carter, N. M. (2003). The Structure of Founding Teams: Homophily, Strong Ties, and Isolation among U.S. Entrepreneurs. American Sociological Review, 68(2), 195-222. https://doi.org/10.2307/1519766

Schlosser, A. E., Shavitt, S., \& Kanfer, A. (1999). Survey of Internet users' attitudes toward Internet advertising. Journal of Interactive Marketing, 34-54. https://doi.org/10.1002/(SICI)1520-6653(199922)13:3<34::AID-DIR3>3.0.CO;2-R

Schmidt, J. B., \& Spreng, R. A. (1996). A Proposed Model of External Consumer Information Search. Journal of the Academy of Marketing Science, 24(3), 246-256. https://doi.org/10.1177/0092070396243005

Shankar, V., Smith, A. K., \& Rangaswamy, A. (2003). Customer satisfaction and loyalty in online and offline environments. International Journal of Research in Marketing, 20(2), 153-175. https://doi.org/10.1016/S0167-8116(03)00016-8

Skadberg, Y. X., \& Kimmel, J. R. (2004). Visitors' flow experience while browsing a Web site: Its measurement, contributing factors and consequences. Computers in Human Behavior, 20(3), 403-422. https://doi.org/10.1016/S0747-5632(03)00050-

Thong, J. Y. L., Hong, S.-J., \& Tam, K. Y. (2006). The effects of post-adoption beliefs on the expectation-confirmation model for information technology continuance. International Journal of Human-Computer Studies, 64(9), 799-810. https://doi.org/10.1016/j.ijhcs.2006.05.001

Tsang, M. M., Ho, S.-C., \& Liang, T.-P. (2004). Consumer Attitudes toward Mobile Advertising: An Empirical Study. International Journal of Electronic Commerce, 8(3), 65-78. https://doi.org/10.1080/10864415.2004.11044301

Xiang, L., Zheng, X., Lee, M. K. O., \& Zhao, D. (2016). Exploring consumers' impulse buying behavior on social commerce platform: The role of parasocial interaction. International Journal of Information Management, 36(3), 333-347. https://doi.org/10.1016/j.ijinfomgt.2015.11.002

Xue, F., \& Phelps, J. E. (2004). Internet-facilitated consumer-to-consumer communication: the moderating role of receiver characteristics. International Journal of Internet Marketing and Advertising, 1(2), 121-136. https://doi.org/10.1504/IJIMA.2004.004016

Yoo, J., Arnold, T. J., \& Frankwick, G. L. (2012). Effects of positive customer-to-customer service interaction. Journal of Business Research, 65(9), 1313-1320. https://doi.org/10.1016/j.jbusres.2011.10.028

Zhou, T. (2011). Examining the critical success factors of mobile website adoption. Online Information Review, 35(4), 636-652. https://doi.org/10.1108/14684521111161972

\section{Copyrights}

Copyright for this article is retained by the author, with first publication rights granted to the journal.

This is an open-access article distributed under the terms and conditions of the Creative Commons Attribution license (http://creativecommons.org/licenses/by/4.0/). 